УДК 621.373.826.032:534.232.082.73

DOI: https://doi.org/10.26642/ten-2020-1(85)-97-103

\author{
К.В. Базіло, к.Т.Н., доц. \\ Черкаський державний технологічний університет \\ В.С. Антонюк, д.т.н., проф. \\ Національний технічний університет України \\ «Київський політехнічний інститут імені Ігоря Сікорського» \\ Л.Г. Полонський, д.Т.н., проф. \\ В.Д. Головня, к.пед.н. \\ Державний університет «Житомирська політехніка»
}

\title{
Розрахунок електричного імпедансу п'єзокерамічного диска в області високих частот
}

\begin{abstract}
Актуальність застосування різних функціональних елементів n'єзоелектроніки в силових $i$ інформаційних системах пояснюється, пери за все, їх високою надійністю. В результаті дослідження математичної моделі реального пристрою можна визначити той набір геометричних, фізико-механічних та електричних параметрів реального об 'єкта, який забезпечує реалізацію технічних показників функиіонального елемента п'єзоелектронік, щзо обумовлені в технічному завданні. Це істотно скорочує час $i$ вартість розробки нових функціональних елементів п'єзоелектроніки.

У статті на основі методу усереднення вирішена система диференціальних рівнянь $у$ часткових похідних та побудована математична модель електричного імпедансу n'єзокерамічного диска в області високих частот, де вектор зміщення матеріальних частинок визначається радіальним і осьовим компонентами.
\end{abstract}

Ключові слова: тонкий диск; п'єзокераміка; електричний імпеданс; вектор зміщення матеріальних частинок.

Актуальність роботи. Актуальність застосування різних функціональних елементів п’єзоелектроніки в силових й інформаційних системах пояснюється, перш за все, їх високою надійністю. Одним із основних елементів таких систем є п'єзокерамічний трансформатор [1], який є альтернативою електромагнітним трансформаторам у тих сферах їх застосування, де необхідна висока надійність, стабільність, автономність, максимальна тривалість безвідмовної роботи [2].

П'єзоелектричний трансформатор має низку переваг порівняно з електромагнітним, а саме [3, 4]: високу питому потужність; відсутність електромагнітних завад; високу ефективність; можливість мініатюризації; широкий частотний діапазон; вогнестійкість; проста технологія виготовлення. Надзвичайно широкі можливості п'єзотрансформаторів дозволяють використовувати їх під час створення різноманітних аналогових і дискретних пристроїв перетворення сигналів, знаходити широке застосування в світлотехнічній апаратурі і приладах переміщення [5-9].

Використання п'єзотрансформаторів стримується складністю адекватного аналітичного опису їх моделей [10]. Кінцевою метою математичного моделювання фізичного стану коливальних п’єзокерамічних елементів є якісний і кількісний опис характеристик і параметрів існуючих в них електричних і пружних полів, що дозволить прогнозувати їх надійність.

Відомо [11-13], що під час опису різних форм коливань одного і того ж об'єкта використовуються різні набори матеріальних констант [14]. Для побудови несуперечливої методики експериментального визначення матеріальних констант п'єзокераміки, яка надає достовірні значення мінімум трьох модулів пружності, двох елементів матриці п'єзомодулів і одного елемента матриці діелектричної проникності, необхідно послідовно розглянути електричний імпеданс коливального п'єзокерамічного диска в області низьких, середніх і високих частот $[15,16]$.

Метою роботи є розрахунок електричного імпедансу коливального диску в області високих частот.

Проведення розрахунків та обговорення їх результатів. В області високих частот, коли довжина пружної хвилі стає сумірною 3 товщиною диска, вектор зміщення матеріальних частинок володіє і радіальним, і осьовим компонентами. Електричний імпеданс коливального п'єзокерамічного диска визначений у [15] формулою (29).

Усереднений по товщині диска радіальний компонент $u_{\rho}^{(z)}(\rho)$ вектора зміщення матеріальних частинок диска має задовольняти рівняння (18) [16]. Усереднений за площею електродованої поверхні аксіальний компонент $u_{z}^{(\rho)}(z)$ повинен задовольняти рівняння:

$$
\frac{\partial \sigma_{z z}^{(\rho)}(z)}{\partial z}+\rho_{0} \omega^{2} u_{z}^{(\rho)}(z)=0
$$


яке виходить з рівняння усталених осьових коливань (вираз (6) в роботі [15]) після застосування до нього процедури усереднення (формула (24) в роботі [15]).

Проводячи розрахунки у порядку запропонованому в [15], отримаємо усереднений по площі електродованої поверхні диска аксіальний компонент вектора напруженості електричного поля:

$$
E_{z}^{(\rho)}(z)=-\frac{U_{0}}{\alpha}--\frac{e_{33}}{\chi_{33}^{\varepsilon}}\left\{\frac{\partial u_{z}^{(\rho)}(z)}{\partial z}-\frac{1}{\alpha}\left[u_{z}^{(\rho)}(\alpha)-u_{z}^{(\rho)}(0)\right]\right\} .
$$

Для тонкого диска справедлива оцінка: $u_{z}(\rho, \alpha)-u_{z}(\rho, 0) \cong u_{z}^{(\rho)}(\alpha)-u_{z}^{(\rho)}(0)$. Урахування цього факту та розв'язок рівняння (18) [16] приводить до такого результату:

$$
\rho^{2} \frac{\partial^{2} u_{\rho}^{(z)}(\rho)}{\partial \rho^{2}}+\rho \frac{\partial u_{\rho}^{(z)}(\rho)}{\partial \rho}+\left[\left(\lambda^{E} R\right)^{2}-1\right] u_{\rho}^{(z)}(\rho)=0,
$$

де $\lambda^{E}=\omega / \sqrt{c_{11}^{E} / \rho_{0}}-$ хвильове число радіальних коливань п'єзокерамічного диска в області високих частот, коли $\sigma_{z z}(\rho, z) \neq 0$. Рішення рівняння (3) очевидне:

$$
u_{\rho}^{(z)}(\rho)=C J_{1}\left(\lambda^{E} \rho\right) \text {, }
$$

де $C$ - частотно залежна константа, що підлягає визначенню.

Вважаючи, що для тонкого диска справедлива оцінка $u_{\rho}(R, z) \cong u_{\rho}^{(z)}(R)$, отримуємо такий результат:

$$
\sigma_{z z}^{(\rho)}(z) \cong \frac{2 c_{12}^{E}}{R} u_{\rho}^{(z)}(R)+c_{33}^{D} \frac{\partial u_{z}^{(\rho)}(z)}{\partial z}-\frac{e_{33}^{2}}{\chi_{33}^{\varepsilon} \alpha}\left[u_{z}^{(\rho)}(\alpha)-u_{z}^{(\rho)}(0)\right]+\frac{e_{33}}{\alpha} U_{0},
$$

де $c_{33}^{D}=c_{33}^{E}\left(1+K_{33}^{2}\right) ; K_{33}^{2}=e_{33}^{2} /\left(\chi_{33}^{\varepsilon} c_{33}^{E}\right)-$ квадрат коефіцієнта електромеханічного зв'язку для режиму товщинних коливань поляризованої по товщині п'єзокерамічної пластинки.

Підставляючи вираз (5) в рівняння (1), приводимо його до такого вигляду:

$$
\frac{\partial^{2} u_{z}^{(\rho)}(z)}{\partial z^{2}}+\gamma^{2} u_{z}^{(\rho)}(z)=0,
$$

де $\gamma=\omega / \sqrt{c_{33}^{D} / \rho_{0}}-$ хвильове число аксіальних (товщинних) коливань п'єзокерамічного диска. Рішення рівняння (6) очевидне:

$$
u_{z}^{(\rho)}(z)=A \cos \gamma z+B \sin \gamma z,
$$

де $A$ і $B$ - частотно залежні константи, що визначаються так:

$$
A=-\frac{e_{31} U_{0}}{\gamma \alpha c_{12}^{E}} \frac{\Delta(A)}{\Delta_{0}}, B=-\frac{e_{31} U_{0}}{\gamma \alpha c_{12}^{E}} \frac{\Delta(B)}{\Delta_{0}}, C=-\frac{e_{31} U_{0}}{\gamma \alpha c_{12}^{E}} \frac{\Delta(C)}{\Delta_{0}},
$$

де $\Delta(A), \Delta(B), \Delta(C)$ і $\Delta_{0}$ - визначники матриць відповідних тензорів [15].

Після визначення констант $A, B$ і $C$ можна записати в явному вигляді усереднені зміщення $u_{\rho}^{(z)}(R)$, $u_{z}^{(\rho)}(\alpha)$ і $u_{z}^{(\rho)}(0)$, і визначити вираз для функції $\Xi^{\varepsilon}(\omega)$ (співвідношення (28) в роботі [15]) в явному вигляді:

$$
\Xi^{\varepsilon}(\omega)=\frac{U_{0}}{\Delta_{0}} F^{\varepsilon}(\omega, \Pi),
$$

де $F^{\varepsilon}(\omega, \Pi)$ - функція, що залежить від частоти і набору геометричних і фізико-механічних параметрів (символ П у списку аргументів функціі) диска, числові значення якої задаються формулою:

$$
F^{\varepsilon}(\omega, \Pi)=\frac{2 e_{31}^{2} \alpha}{\chi_{33}^{\varepsilon} c_{12}^{E} R} \Delta(C) \frac{J_{1}\left(\lambda^{E} R\right)}{\gamma \alpha}+\frac{e_{33} e_{31}}{\chi_{33}^{\varepsilon} c_{12}^{E}}\left[-\Delta(A) \frac{(1-\cos \gamma \alpha)}{\gamma \alpha}+\Delta(B) \frac{\sin \gamma \alpha}{\gamma \alpha}\right]+1 .
$$

При цьому електричний імпеданс п’єзокерамічного диска в області високих частот задається таким виразом:

$$
Z_{\text {эл }}(\omega)=\frac{U_{0}}{-i \omega C_{\partial}^{\varepsilon} \Xi^{\varepsilon}(\omega)}=\frac{\Delta_{0}}{-i \omega C_{\partial}^{\varepsilon} F^{\varepsilon}(\omega, \Pi)},
$$

де $C_{\partial}^{\varepsilon}=\pi R^{2} \chi_{33}^{\varepsilon} / \alpha$ - динамічна електрична ємність п'єзокерамічного диска на високих частотах

На рисунку 1 показані результати розрахунків модуля електричного імпедансу диска, які виконувалися за формулою (8) при такому фіксованому наборі параметрів: $c_{11}^{E}=110$ ГПа; $c_{12}^{E}=60$ ГПа; $c_{33}^{E}=100 \Gamma \Pi а ; \quad e_{33}=18 \mathrm{Kл} / \mathrm{M}^{2} ; \quad e_{31}=-8 \mathrm{Kл} / \mathrm{m}^{2}$ i $\chi_{33}^{\varepsilon}=1400 \chi_{0} ; \chi_{0}=8,85 \cdot 10^{-12} \Phi / \mathrm{M}-$ діелектрична постійна; механічна добротність п'єзокераміки $Q_{M}=100$; густина п'єзокераміки $\rho_{0}=7400 \kappa г / \mathrm{M}^{3}$. Товщина диска $\alpha=3 \cdot 10^{-3} \mathrm{M}$.

Варійованим параметром сімейства кривих, показаних на рисунку $1, \epsilon$ співвідношення $R / \alpha$, яке задавалося рівним $100 ; 50 ; 25 ; 12,5$ і 6,25 . Числові значення співвідношення $R / \alpha$ проставлені в полі рисунка біля відповідних кривих. При обумовлених вище значеннях параметрів диска значенням $\gamma \alpha=1$ відповідає циклічна частота $f=v^{D} /(2 \pi \alpha)=219,1$ кГц, де $v^{D}=\sqrt{c_{33}^{D} / \rho_{0}}=4130 \mathrm{м} / \mathrm{c}-$ швидкість поширення плоских хвиль стиснення-розтягування вздовж напрямку електричної поляризації диска.

3 показаних на рисунку 1 результатів випливає, що при значній зміні співвідношення $R / \alpha$, значення безрозмірної частоти першого товщинного електромеханічного антирезонансу залишається практично незмінним. Сказане підтверджують побудови, наведені на рисунку 2, де показані результати обчислення співвідношення $\left|Z_{e l}(\omega)\right| /\left|Z_{e l}\left(\omega_{a}\right)\right|$ в найближчій околиці частоти антирезонансу. 


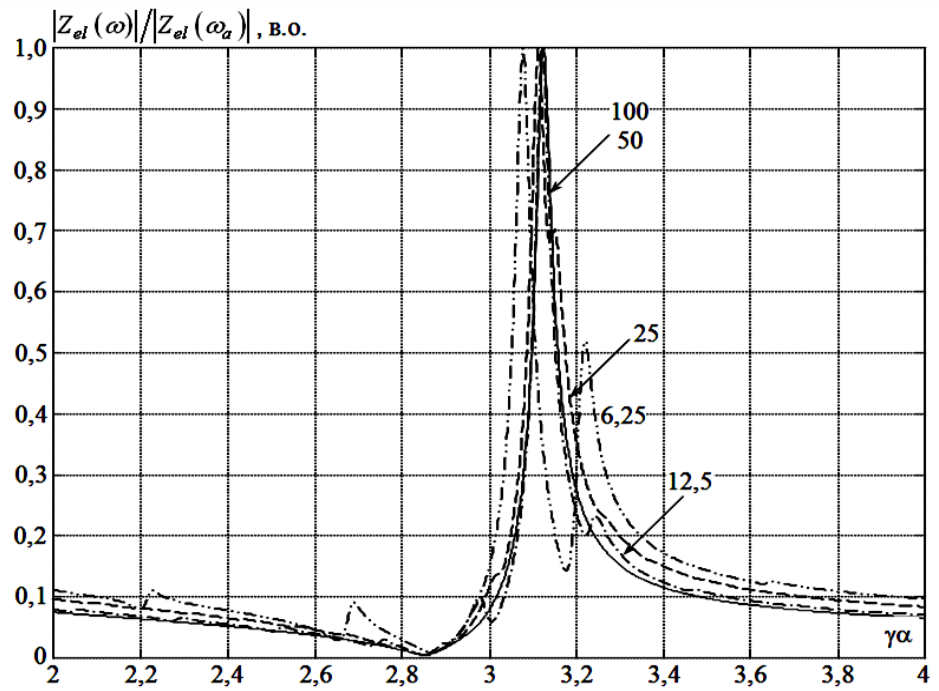

Рис. 1. Частотно залежна зміна модуля електричного імпедансу n'єзокерамічного диска в околиці частоти першого товщчиного електромеханічного резонансу-антирезонансу

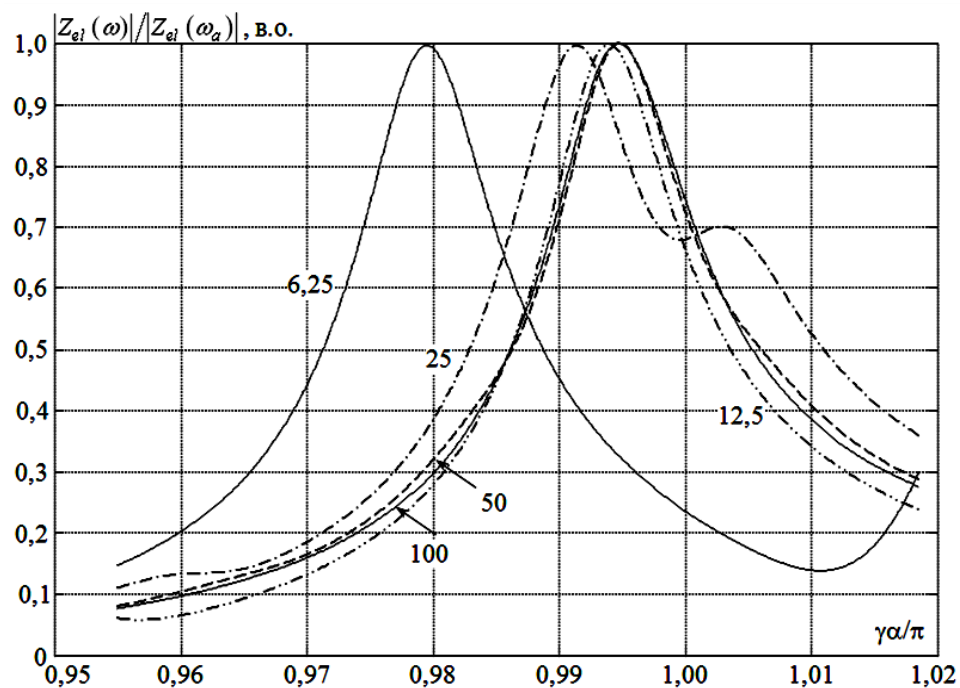

Рис. 2. Частотно залежна зміна модуля електричного імпедансу n'єзокерамічного диска в найближчій околиці частоти перщого товщинного електромеханічного антирезонансу

Чітко видно, що максимально можлива зміна безрозмірної частоти електромеханічного антирезонансу не перевищує $0,02 \pi$. Аналогічний висновок можна зробити про вплив параметра $R / \alpha$ на значення безрозмірної частоти першого товщинного електромеханічного резонансу (рис. 1$)$, де модуль $Z_{e l}(\omega)$ приймає мінімальне значення.

На підставі цього можна зробити висновок, що радіальні зміщення $u_{\rho}^{(z)}(R)$ матеріальних частинок диска практично не впливають на числові значення частот першого товщинного електромеханічного резонансу і антирезонансу, тобто числові значення частот електромеханічного резонансу і антирезонансу практично повністю визначаються аксіальними зсувами $u_{z}^{(\rho)}(z)$ [17].

Беручи до уваги цю обставину, можна стверджувати, що в області високих частот функція $\Xi^{\varepsilon}(\omega)$, яка визначає електричний імпеданс коливального диска в цьому частотному діапазоні, може бути записана в такому вигляді:

$$
\Xi^{\varepsilon}(\omega) \cong \frac{e_{33}}{\chi_{33}^{\varepsilon}}\left[u_{z}^{(\rho)}(\alpha)-u_{z}^{(\rho)}(0)\right]-U_{0}
$$

Під час виконання розрахунку електричного імпедансу за формулою (9), природно, будуть втрачені деякі деталі частотно-залежної зміни функції $Z_{e l}(\omega)$. Зате буде збережено головне - числові значення частот електромеханічного резонансу і антирезонансу. 
У результаті отримуємо систему лінійних алгебраїчних рівнянь, з яких єдиним чином визначаються константи $A$ і $B$ :

$$
A=\frac{e_{33} U_{0}}{c_{33}^{D}} \frac{\operatorname{tg}(\gamma \alpha / 2)}{\gamma \alpha F^{\varepsilon}(\omega, \Pi)}, B=-\operatorname{Atg}(\gamma \alpha / 2),
$$

де

$$
F^{\varepsilon}(\omega, \Pi)=1-\frac{K_{33}^{2}}{1+K_{33}^{2}} \frac{\operatorname{tg}(\gamma \alpha / 2)}{(\gamma \alpha / 2)} .
$$

Підстановка виразів (10) у визначення (17) аксіальних зміщень матеріальних частинок п'єзокерамічного диска, дозволяє визначити величини $u_{z}^{(\rho)}(\alpha)$ і $u_{z}^{(\rho)}(0)$, після чого визначається в явному вигляді функція $\Xi^{\varepsilon}(\omega)$, задана співвідношенням (9). Після цього вираз для розрахунку електричного імпедансу $Z_{e l}(\omega)$ можна записати в такому вигляді:

$$
Z_{e l}(\omega)=\frac{1}{i \omega C_{\partial}^{\varepsilon}} F^{\varepsilon}(\omega, \Pi) .
$$

3 виразу (12) випливає, що при наближенні $\gamma \alpha / 2$ зліва до значення $\pi / 2$, функція $F^{\varepsilon}(\omega, \Pi)$ спочатку має позитивні значення, далі обертається в нуль, що відповідає електромеханічного резонансу, а ще далі спрямовується до мінус нескінченності. У разі відсутності втрат енергії на в'язке тертя в матеріалі п'єзокерамічного диска $\left(Q_{\mathrm{M}} \rightarrow \infty\right)$ при $\gamma \alpha=\pi$ електричний імпеданс $Z_{e l}\left(\omega_{a}\right) \rightarrow \infty$.

На рисунку 3 , а показана зміна функції $F^{\varepsilon}(\omega, \Pi)$ для випадку $Q_{M} \rightarrow \infty$ і $K_{33}^{2}=0,262$, що відповідає набору фізико-механічних параметрів, які були використані під час розрахунків кривих, які показані на рисунках 1 i 2.

На рисунку 3, б показаний нормований на своє максимальне значення модуль комплекснозначної функції $F^{\varepsilon}(\omega, \Pi)$, коли механічна добротність матеріалу диска $Q_{M}=100$ і безрозмірне хвильове число $\gamma \alpha$ стає комплексним числом $\gamma \alpha\left(1-i /\left(2 Q_{M}\right)\right)$.
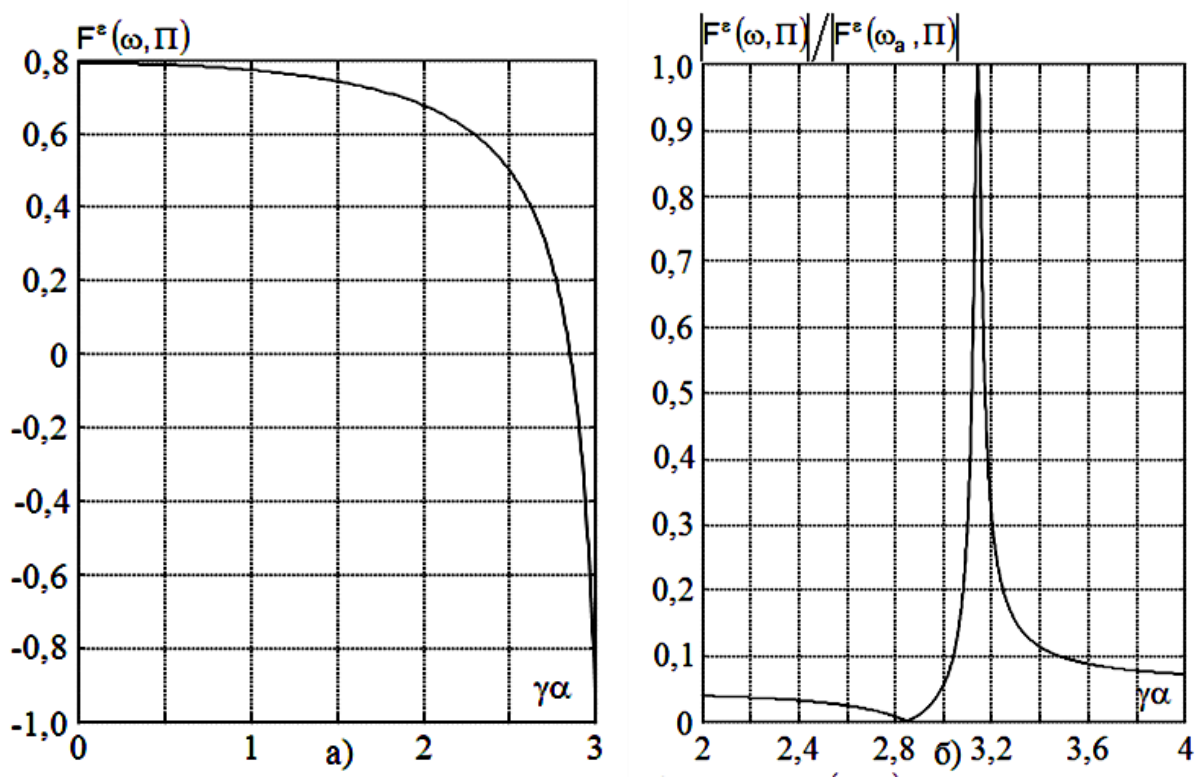

Рис. 3. Частотно залежна зміна функції $F^{\varepsilon}(\omega, \Pi)$ за відсутності втрат енергії в матеріалі диска (a) $i$ для механічної добротності $Q_{M}=100$ (б)

Порівнюючи криві, які показані на рисунках 1 і 3, б, можна зробити висновок, що деталізований розрахунок електричного імпедансу коливального п'єзокерамічного диска слід здійснювати за формулою (8), а оцінку числових значень частот резонансу і антирезонансу виконувати з використанням функції $F^{\varepsilon}(\omega, \Pi)$, яка задана виразом (11).

Завершуючи дослідження електричного імпедансу п'єзокерамічного диска в області високих частот, розглянемо його значення на частоті першого електромеханічного резонансу.

Розкладаючи вираз (12) на частоті першого електромеханічного резонансу в ряд за ступенями малого параметра $\varepsilon$, і обмежуючись при цьому нульовим і першим членами розкладання, отримуємо:

$$
Z_{e l}\left(\omega_{p}\right)=\varepsilon \frac{K_{33}^{2} \Psi\left(\omega_{p}\right)}{\omega_{p} c_{\partial}^{\varepsilon}\left(1+K_{33}^{2}\right)},
$$

де $K_{33}^{2}=\frac{e_{33}^{2}}{\chi_{33}^{\varepsilon} c_{33}^{E}}$;

$$
\Psi\left(\omega_{p}\right)=\frac{2 \operatorname{tg}\left(\gamma^{0} \alpha / 2\right)}{\left(1+K_{33}^{2}\right)\left(\gamma^{0} \alpha / 2\right)}+\frac{1+\sin \left(\gamma^{0} \alpha\right) /\left(\gamma^{0} \alpha\right)}{\cos ^{2}\left(\gamma^{0} \alpha / 2\right)} .
$$


На рисунку 4 наведено графіки модуля електричного імпедансу $Z_{e l}(\omega)$, розраховані за формулою (8) в найближчій околиці частоти першого електромеханічного резонансу.

Розрахунки виконувалися для диска зі співвідношенням $R / \alpha=12,5$. Інші параметри вказані в коментарях до рисунка 1 . Змінним параметром сімейства кривих на рисунку $4 \epsilon$ механічна добротність $Q_{M}$, якій присвоювалися значення 60, 80, 100 і 120 одиниць. Значення добротності проставлені біля відповідних кривих. Чітко видно, що найбільшому значенню $Q_{M}$ відповідає найменше значення електричного імпедансу $Z_{e l}\left(\omega_{p}\right)$, який, як випливає з (13), має позитивні дійсні значення, тобто $\left|Z_{e l}\left(\omega_{p}\right)\right| \equiv Z_{e l}\left(\omega_{p}\right)$.

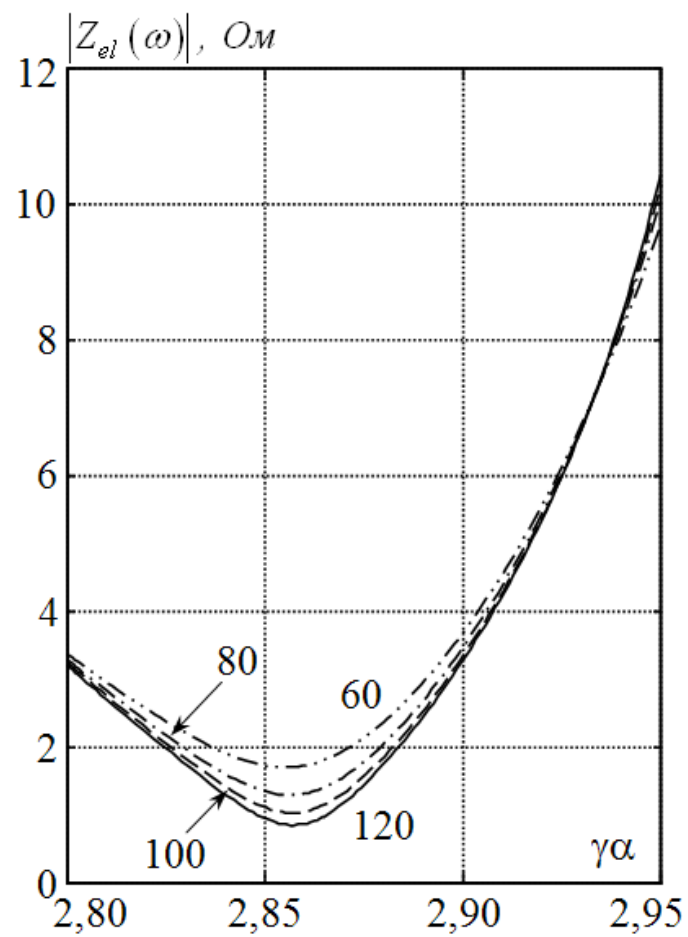

Рис. 4. Розрахунок за формулою (8) модуля електричного імпедансу диска в околиці частоти першого електромеханічного резонансу

Висновки. Таким чином, за допомогою методу усереднення вирішена система диференціальних рівнянь у часткових похідних і на цій основі побудована математична модель електричного імпедансу п’єзокерамічного диска в області високих частот, де вектор зміщення матеріальних частинок визначається радіальним і осьовим компонентами. У результаті дослідження математичної моделі реального пристрою визначено той набір геометричних, фізико-механічних та електричних параметрів реального об'єкта, який забезпечує реалізацію технічних показників функціонального елемента п'єзоелектроніки обумовлених в технічному завданні до цього елемента. Це істотно скорочує час і вартість розробки нових функціональних елементів п’єзоелектроніки, а також систем їхнім керуванням [18].

\section{Список використаної літератури:}

1. Исследование характеристик пьезоэлектрического трансформатора на основе радиальных колебаний в тонких пьезокерамических дисках / А.В. Богдан, О.Н. Петрищев, Ю.И. Якименко, Ю.Ю. Яновская // Электроника и связь. Тематический выпуск «Электроника и нанотехнологии». - 2009. - Ч. 1. - С. $269-274$.

2. Математическое моделирование колебаний тонких пьезокерамических дисков для создания функциональных элементов пьезоэлектроники / А.В. Богдан, О.Н. Петрищев, Ю.И. Якименко, Ю.Ю. Яновская // Электроника и связь. Тематический выпуск «Электроника и нанотехнологии». - 2009. Ч. 2. - C. 35-42.

3. Hsu Yu-Hsiang Electrical and Mechanical Fully Coupled Theory and Experimental Verification of Rosen-Type Piezoelectric Transformers / Yu-Hsiang Hsu, Chih-Kung Lee, Wen-Hsin Hsiao // IEEE Transactions on Ultrasonics, Ferroelectrics and Frequency Control. - 2005. - Vol. 52. - No. 10. - P. 1829-1839.

4. Flynn Anita M. Fundamental Limits on Energy Transfer and Circuit Considerations for Piezoelectric Transformers / Anita M. Flynn, Seth R. Sanders // IEEE Trans. on Power Electron. - 2002. - Vol. 17, No. 1. - P. 8-14.

5. Новые области применения пьезотрансформаторов / В.М. Климашин, В.Г. Никифоров, А.Я. Сафронов, В.К. Казаков // Компоненты и технологии. - 2004. - № 1. - С. 56-60. 
6. Day Michael Understanding piezoelectric transformers in CCFL backlight applications / Michael Day, Bang S. Lee // Analog Applications Journal. - 2002. - 4 Q. - P. 18-24.

7. Wells Eddy Comparing magnetic and piezoelectric transformer approaches in CCFL applications / Eddy Wells // Analog Applications Journal. - 2002. - 1 Q. - P. 12-18.

8. Новаковский А.Г. Применения пьезоэлектрических актуаторов в микроманипуляторах / А.Г. Новаковский, B.С. Антонюк, С.Ф. Петренко // Вісник Черкаського державного технологічного університету. - Черкаси, 2017. - № 4. - C. 5-10.

9. Comparison of piezoelectric and DC motor control principles / S.F. Petrenko, A.V. Omelyan, V.S. Antonyuk, O.G. Novakovskyi // Journal of Nano- and Electronic Physics. - 2018. - Vol. 10. - Issue 5. - No. 05032

10. Експериментальні частотні характеристики п'єзотрансформатора поперечно-поперечного типу для стабілізації струму люмінесцентної лампи / О.Шкодзінський, І.Бєлякова, В.Пісьціо, В.Медвідь // Вісник ТНТУ. - 2011. - Т. 16. - № 3. - С. 142-148.

11. Гринченко В.Т. Механика связанных полей в элементах конструкций. Т. 5. Электроупругость / В.Т. Гринченко, А.Ф. Улитко, Н.А. Шульга. - К. : Наукова думка, 1989. - 280 с.

12. Исследование резонансных характеристик осцилятора пьезоелектрических двигателей / A.B. Омелян, С.Ф. Петренко, А.Г. Новаковский, В.С. Антонюк // Материалы II Международной научно-технической конференции «Приборостроние-2018» (14-18 ноября 2018 г.). - Минск, Республика Беларусь, 2018. - С. 155-156.

13. Резонансні характеристики п'єзоелектричного двигуна в залежності від ресурсного стану / С.Ф. Петренко, А.В. Омелян, О.О. Горбатюк, В.С. Антонюк // Наукові вісті Національного технічного університету України «Київський політехнічний інститут імені Ігоря Сікорського». - К., 2019. - № 1. - С. 59-66.

14. Партон В.3. Электромагнитоупругость пьезоэлектрических и электро-проводных тел / В.3. Партон, Б.А. Кудрявиев. - М. : Наука, 1988. - 472 с.

15. Петрищев О.Н. Определение электрического импеданса пьезокерамического диска и его расчет в области низких частот / О.Н. Петрищев, К.В. Базило // Вісник Черкаського державного технологічного університету. - Черкаси, 2016. - № 3. - С. 24-35.

16. Базіло К.В. Принципи розрахунку електричного імпедансу коливального п'єзокерамічного диску в області середніх частот / К.В. Базіло // Радіоелектроніка, інформатика, управління. - Запоріжжя, 2017. - № 4. - С. 15-25.

17. Исследование сопутствующего ударно-вибрационного шума пьезоэлектрического двигателя в режиме микро- и наноскоростей / С.Ф. Петренко, А.В. Омелян, А.Н. Лысенко, В.С. Антонюк // Вісник Національного технічного університету України «Київський політехнічний інститут імені Ігоря Сікорського». - К., 2019. № 78. - С. 67-73.

18. Система керування п'єзоелектричним двигуном / С.Ф. Петренко, А.В. Омелян, В.С. Антонюк, О.Г. Новаковський // Вісник Національного технічного університету України «Київський політехнічний інститут». - К., 2018. - Вип. 55. - № 1. - С. 5-10.

\section{References:}

1. Bogdan, A.V., Petrishchev, O.N., Yakimenko, Yu.I. and Yanovskaya, Yu.Yu. (2009), «Issledovanie kharakteristik p'ezoelektricheskogo transformatora na osnove radial'nykh kolebanii v tonkikh p'ezokeramicheskikh diskakh», Elektronika i svyaz', Tematicheskii vypusk Elektronika i nanotekhnologii, Part 1, pp. 269-274.

2. Bogdan, A.V., Petrishchev, O.N., Yakimenko, Yu.I. and Yanovskaya, Yu.Yu. (2009), «Matematicheskoe modelirovanie kolebanii tonkikh p'ezokeramicheskikh diskov dlya sozdaniya funktsional'nykh elementov p'ezoelektroniki», Elektronika i svyaz', Tematicheskii vypusk Elektronika i nanotekhnologii, Part 2, pp. 35-42.

3. Yu-Hsiang, Hsu, Chih-Kung, Lee and Wen-Hsin, Hsiao (2005), «Electrical and Mechanical Fully Coupled Theory and Experimental Verification of Rosen-Type Piezoelectric Transformers», IEEE Transactions on Ultrasonics, Ferroelectrics and Frequency Control, Vol. 52, No. 10, pp. 1829-1839.

4. Flynn, Anita M. and Sanders, Seth R. (2002), «Fundamental Limits on Energy Transfer and Circuit Considerations for Piezoelectric Transformers», IEEE Transactions on Power Electronics, Vol. 17, No. 1, pp. 8-14.

5. Klimashin, V.M., Nikiforov, V.G., Safronov, A.Ya. and Kazakov, V.K. (2004), «Novye oblasti primeneniya p'ezotransformatorov», Komponenty i tekhnologii, No. 1, pp. 56-60.

6. Day, Michael and Lee, Bang S. (2002), «Understanding piezoelectric transformers in CCFL backlight applications», Analog Applications Journal, 4 Q, pp. 18-24.

7. Wells, Eddy (2002), «Comparing magnetic and piezoelectric transformer approaches in CCFL applications», Analog Appl. Journal, 1 Q, pp. 12-18.

8. Novakovskii, A.G., Antonyuk, V.S. and Petrenko S.F. (2017), «Primeneniya pezoelektricheskih aktuatorov v mikromanipulyatorah», Visnyk Cherkas'kogo derzhavnogo tehnologichnogo universytetu, Cherkasy, No. 4, pp. 5-10.

9. Petrenko, S.F., Omelyan, A.V., Antonyuk, V.S. and Novakovskyi, O.G. (2018), «Comparison of piezoelectric and DC motor control principles», Journal of Nano- and Electronic Physics, Vol. 10, Issue 5, No. 05032

10. Shkodzins'kyj, O., Bjeljakova, I., Pis'cio, V. and Medvid', V. (2011), «Eksperymental'ni chastotni harakterystyky p'jezotransformatora poperechno-poperechnogo typu dlja stabilizacii' strumu ljuminescentnoi' lampy», Visnyk TNTU, Vol. 16, No. 3, pp. 142-148.

11. Grinchenko, V.T., Ulitko, A.F. and Shul'ga, N.A. (1989), Mekhanika svyazannykh polei v elementakh konstruktsii. T. 5. Elektrouprugost', Naukova dumka, Kiev, 280 p.

12. Omelyan, A.V., Petrenko, S.F., Novakovskii, A.G. and Antonyuk, V.S. (2018), «Issledovanie rezonansnykh kharakteristik ostsilyatora p'ezoelektricheskikh dvigatele», Materialy II Mezhdunarodnoi nauchno-tekhnicheskoi konferentsii «Priborostronie-2018», (14-18 noyabrya 2018 g.), Minsk, Respublika Belarus', pp. 155-156. 
13. Petrenko, S.F., Omeljan, A.V., Gorbatjuk, O.O. and Antonjuk, V.S. (2019), «Rezonansni harakterystyky p'jezoelektrychnogo dvyguna v zalezhnosti vid resursnogo stanu», Naukovi visti Nacional'nogo tehnichnogo universytetu Ukrai'ny «Kyi'vs'kyj politehnichnyj instytut imeni Igorja Sikors'kogo», No. 1, pp. 59-66.

14. Parton, V.Z. and Kudryavtsev, B.A. (1988), Elektromagnitouprugost' p'ezoelektricheskikh i elektro-provodnykh tel, Nauka, Moskva, 472 p.

15. Petrishchev, O.N. and Bazilo, C.V. (2016), «Opredelenie elektricheskogo impedansa p'ezokeramicheskogo diska i ego raschet v oblasti nizkikh chastot», Visnyk Cherkas'kogo derzhavnogo tehnologichnogo universytetu, Cherkasy, No. 3, pp. 24-35.

16. Bazilo, C.V. (2017), «Pryncypy rozrahunku elektrychnogo impedansu kolyval'nogo p’jezokeramichnogo dysku v oblasti serednih chastot», Radioelektronika, informatyka, upravlinnja, Zaporizhzhja, No. 4, pp. 15-25.

17. Petrenko, S.F., Omelyan, A.V., Lysenko, A.N. and Antonyuk, V.S. (2019), «Issledovanie soputstvuyushchego udarno-vibratsionnogo shuma p'ezoelektricheskogo dvigatelya v rezhime mikro- i nanoskorostei», Visnyk Nacional'nogo tehnichnogo universytetu Ukrai'ny «Kyi'vs'kyj politehnichnyj instytut imeni Igorja Sikors'kogo», Kyiv, No. 78 , pp. 67-73

18. Petrenko, S.F., Omelyan, A.V., Antonyuk, V.S. and Novakovskii, O.H. (2018), «Systema keruvannja p'jezoelektrychnym dvygunom», Visnyk Nacional'nogo tehnichnogo universytetu Ukrai'ny «Kyi'vs'kyj politehnichnyj instytut imeni Igorja Sikors'kogo», Kyiv, Issue 55, No. 1, pp. 5-10.

Базіло Костянтин Вікторович - кандидат технічних наук, доцент, докторант, доцент кафедри приладобудування, мехатроніки та комп'ютеризованих технологій Черкаського державного технологічного університету.

Наукові інтереси:

- п’єзоелектричні перетворювачі;

- математичне моделювання.

E-mail: b_constantine@ukr.net.

Антонюк Віктор Степанович - доктор технічних наук, професор, в. о. завідувача кафедри виробництва приладів Національного технічного університету України «Київський політехнічний інститут імені Ігоря Сікорського».

Наукові інтереси:

- обробка матеріалів різанням;

- наукове приладобудування.

E-mail: viktor.antoniuk@gmail.com.

Полонський Леонід Григорович - доктор технічних наук, професор, завідувач кафедри прикладної механіки і комп'ютерно-інтегрованих технологій Державного університету «Житомирська політехніка».

Наукові інтереси:

- обробка металів різанням.

E-mail: pol@ztu.edu.ua.

Головня В'ячеслав Дмитрович - кандидат педагогічних наук, доцент кафедри прикладної механіки і комп’ютерно-інтегрованих технологій Державного університету «Житомирська політехніка».

Наукові інтереси:

- обробка металів різанням;

- верстати з ЧПК;

- САПР.

E-mail: v.holovnia@ztu.edu.ua. 